\title{
Fake News as a Democratic Anathema: A Comparative Study between India and Indonesia
}

\author{
Ishita Sharma*, Mansi Aggarwal \\ School of Law, University of Petroleum \& Energy Studies, India. \\ *Correspondign author's e-mail: isharma@ddn.upes.ac.in
}

\begin{tabular}{l} 
ARTICLE INFO \\
\hline Keywords: \\
Fake News; India; Media; \\
Policy; Social Media \\
How to cite: \\
Sharma, I., Aggarwal, M. \\
(2019). Fake News as a \\
Democratic Anathema: A \\
Comparative Study \\
between India and \\
Indonesia, Hasanuddin \\
Law Review, 5 (3): $266-$ \\
277 \\
DOI: \\
10.20956/halrev.v3i3.2033
\end{tabular}

\begin{abstract}
The undeniably mind boggling media landscape has tossed fresh difficulties to an unsettled environment of media policy and that is why the market is denuded with fake news: scattered through social media intermediaries. Absence of effective laws for the same, have worsened the situation in recent past. Through this paper the researchers have tried to inspect how the propagation of fake news has upset the public sphere and potential arrangements that can be executed to check the plague of fake news in context of India and Indonesia, the prime democracies. There is boisterous discussion on fake news being utilized to create a rosy impression of the politicians in the minds of citizens. Therefore, the researcher shall also cover this aspect by analyzing how fake news has affected elections and how it was used as a tool of mass deception respectively. Finally, it attempts to analyze various strategic initiatives taken by both the nations, and the potential measures which could be adopted to limit the progression of fake news.
\end{abstract}

Copyright (C) 2019 HALREV. All rights reserved.

\section{Introduction}

Blatantly false data available on the Internet proposed to influence belief is fake news. ${ }^{1}$ Due to changes in media technology, the Indian democracy has been over and again battered. During 19th century partisan newspaper were permitted to grow their clout significantly. Many have argued that the efficacy of the press due to self-regulation was essentially compromised subsequently. In twentieth century radio and then television occupied a dominant position in the market where in observers stressed that these new platforms would decrease substantive policy debates, and would choose charismatic candidates over those individuals who may have greater capacity to lead

1 Flick, D. (2017). Combatting fake news: Alternatives to limiting social media misinformation and rehabilitating quality journalism. SMU Science and Technology Law Review, 20(2), 375. 
however less polished and full control would go into the hands of huge corporations. Development of online news, in the mid 2000's, provoked another medley of worries, the prime being variety of perspectives that would make it easier for like-minded people to form groups or chambers or filter bubbles ${ }^{2}$ where they would be protected from opposite point of view. ${ }^{3}$

In the past few years, the focal point of concern has shifted to social media like WhatsApp, Facebook and Twitter that have drastically different structure than previous technologies. An individual with no reputation or a non-journalist can reach out to as many readers as he wants and will spread "fake news". Now a day's people think that -"fake news is not a term that was utilized by many people earlier, however it is currently observed as perhaps the biggest danger to democracy", but according to the researchers, it is not something, which has been catalyzed in a digital age alone; it has been a long-standing problem. The only difference is that now it is spread through digital platform, due to its increased use. However it has become a hot topic in 2017. While there is a shift in the definition of "fake news" which states that- Blatantly false data proposed on the Internet meant to influence belief.4 Just as being a most loved term of Donald trump, it was likewise named 2017's word of the year, raising tension among countries, and may lead to regulation of social media. ${ }^{5}$

The expression "fake news" has entered academia and even every day discussion, summoned not just in endeavors to call attention to false data but also in endeavors to disparage traditional news corporation. So understanding the idea of fake news is significant. Such an attempt will assist in finding out the root cause i.e. what causes individuals to indulge in fake news. Since the term isn't new, and has been utilized in different contexts, it is helpful to evaluate the different ways in which fake news could be defined. ${ }^{6}$

In the paper researchers will be analyzing the two of the most prime democracies (India and Indonesia) on the planet where the vile phenomena of fake news has had potential effect on elections which took place in the summer of April to May 2019. This paper also analyses the outcomes of the exponential development and existing frameworks set up to encourage the change with regards to fake news in the abovementioned countries.

2 When we go on the web or login to a social network we are given news, articles and substance dependent on our own pursuits on the web. This sort of substance will in general mirror our own preferences, perspectives and convictions and in this manner segregating us from varying perspectives and assessments. This is regularly alluded to as a filter bubble.

3 Allcott, H., \& Gentzkow, M. (2017). Social Media and Fake News in the 2016 Election. The Journal of Economic Perspectives,31(2), 211. Retrieved from http://www.jstor.org/stable/44235006

${ }^{4}$ Dallas Flick, Combating Fake News: Alternatives to Limiting Social Media Misinformation and Rehabilitating FQuality Journalism, 20 SMU Sci. \& Tech. L. Rev. 375 (2017).

${ }^{5}$ Carson, J. (2019). Fake news: What exactly is it - and how can you spot it?. Retrieved 5 Septemb 2019, from https://www.telegraph.co.uk/technology/0/fake-news-exactly-has-really-had-influence/

6 Edson, T., Lim Zheng, W., \& rich, L. (2019). Defining "Fake News": A typology of scholarly definitions. $\quad$ Retrieved 13 September 2019, from https://www.researchgate.net/publication/319383049_Defining_Fake_News_A_typology_of_scholarly_definitions. 


\section{Overview of Fake News}

The word "fake news" does not have a specific connotation. ${ }^{7}$ This is on the ground that the term "news" signifies unquestionable data in public interest.8Then, 'fake news' is an oxymoron which fits itself to undermining the quality of data to meet the threshold of undeniable nature and public policy-i.e. genuine news. ${ }^{9}$ A recent study defined fake news "to be news articles that are intentionally and verifiably false, and could mislead leaders". 10

According to Claire Wardle "fake news" has a large ambit which consist of disinformation and misinformation, ${ }^{11}$ where in the Oxford Dictionary defines misinformation as "the act of giving wrong information about something" 12 and disinformation as "false information that is given deliberately" 13 . Both are problematic for society yet disinformation is especially perilous in light of the fact that it is much of the time sorted out, well resourced and reinforced via advanced technology. ${ }^{14} \mathrm{~A}$ specific threat in the "fake news" is that the people who can't pay for quality reporting, or who need access to free open administration of news media, are particularly powerless against both misinformation and disinformation.

According to Lazer et al, fake news is fabricated information that mimics news media content in form but not in organizational process or intent. Fake-news outlets, in turn, lack the news media's editorial norms and processes for ensuring the accuracy and credibility of information. Fake news overlaps with other information disorders, such as misinformation (false or misleading information) and disinformation (false information that is purposely spread to deceive people). ${ }^{15}$ The French law is the first legislative act which defines "fake laws" as an inexact allegations or imputations, or news that falsely report facts, with the aim of changing the sincerity of a vote.

Goliath man-bats that went through gathering leafy foods enlivened discussions; goatlike animals with blue skin; a temple made of cleaned sapphire. These were the surprising sights seen by John Herschel, a famous British space expert, when, in 1835, he pointed a ground-breaking telescope "of huge measurements" towards the Moon from an observatory in South Africa. 16 Or on the other hand that was what readers of the New York Sun were told in a progression of paper reports.

This created uproar. People ran to purchase every day's release of the Sun. The paper's course shot up from 8,000 to more than 19,000 duplicates, surpassing the Times of London to turn into the world's best news paper. There was only one little hitch. The fantastical reports had in truth been composed by Richard Adams Locke, the Sun's

7 Tandoc, E., Lim, Z., \& Ling, R. (2017). Defining “Fake News". Digital Journalism, 6(2), 137-153. doi: 10.1080/21670811.2017.1360143

8 Carson, J. Supra note 6.

9 Ireton, Supra note 2.

10 Supra note 4 , at 213.

11 Fake news. It's complicated. (2019). Retrieved 6 September 2019, from https://medium.com/1stdraft/fake-news-its-complicated-d0f773766c79.

12 Misinformation. (2019). Oxford learners dictionaries. Retrieved 5 September, 2019, from https://www.oxfordlearnersdictionaries.com/definition/english/misinformation.

13 Id.

14 Ireton, Supra note 2, at 7.

15 Lazer, D., Baum, M., Benkler, Y., Berinsky, A., Greenhill, K., Menczer, F., Nyhan, B, The science of $\begin{array}{llllll}\text { fake news. (2019). } & \text { Retrieved } & \text { September }\end{array}$ https://scholar.harvard.edu/files/mbaum/files/science_of_fake_news.pdf_news.pdf.

16 Standage, T. (2019). The true history of fake news. Retrieved 7 September 2019, from https://www.1843magazine.com/technology/rewind/the-true-history-of-fake-news 
editorial manager. Herschel was leading authentic galactic perceptions in South Africa. Be that as it may, Locke realized it would take a very long time for his misleading news to be uncovered, in light of the fact that the main methods for communication with the Cape was by letter. ${ }^{17}$ The entire thing was a huge fabrication - or, as we would state today, "fake news".

But they were different, as they keep up heap of various stories, and not only one, and showed up routinely under a constant title. They therefore had a status to maintain i.e. of a bestselling newspaper. For this the best example was which we have discussed above the sun .They were soon exposed by their competition. But after this editor understood that for long sustainability and for maintaining the reputation of their newspaper the supply of certifiable human show could be found by sending reporters to the courts and police headquarters to compose genuine stories ${ }^{18}$. With the progress of nineteenth century, objectivity and fairness were progressively revered at the most esteemed papers.

But, now the newspaper bundles of stories are blown apart due to currently used web crawlers and social media. Facebook demonstrates an interminable stream of things from everywhere throughout the web. Snap an intriguing feature and you may wind up on a fake news site. As the merchants of fake news have no impetus to stay honest and have no reputation either. They are just intrigued by the snaps. To find out motivation for the creation of such fake stories Claire Wardle used Eliot's Higgins original list for P's Poor Journalism, Parody, to Provoke or 'Punk', Passion, Partisanship, Profit, Political Influence or Power, and Propaganda. ${ }^{19}$

Subsequently the false stories, among the most well known of 2016, that the pope had embraced Donald Trump, or that Hillary Clinton had offered weapons to Islamic State which will be dealt by the researchers later. Due to the internet fake news has again become a profitable business for some people. This blooming of manufactured stories erodes trust in the media by and large, and makes it simpler for corrupt politicians to sell misleading statements.

\section{The Sociological Imagination: Tool to Identify Social Problem of Fake News}

C. Wright Mills wrote the book on The Sociological Imagination in which he says that the sociological imagination is an idea that an individual can comprehend her own experience and measure her own destiny just by finding herself in her time, that she can know her own odds in life just by getting to be mindful of those in the same situation. ${ }^{20}$ Mills, wanted people to stop focusing on themselves rather to look at the wider society. He has not restricted to sociology alone he gave it a wider lens. According to him as soon as we start considering different issues from different perspectives and that contrast from our own, that means we are entering the realm of sociological imagination.

17 Id.

$18 \mathrm{Id}$.

19 Claire, Supra note 12.

20 C. Wright Mills. (2019). The Sociological Imagination. Retrieved 7 September 2019, from https://sites.middlebury.edu/utopias/files/2013/02/The-Promise.pdf 
The sociological imagination is a scholarly device which helps us to understand the sociology of knowledge (or nature of reality). In suffice it means notwithstanding the general idea of reality there are sure social certainties and facts that join us in a world.

Applying the above mentioned concept we will get to know, why fake news hits at the heart of our modern information society. ${ }^{21}$ Sources of recorded information are one way that we share and create our reality and represent our society. ${ }^{22}$ Especially news and other information sources play an important role in updating us about the current events happening in the society and world. Public at large is totally dependent on these sources and if these sources does not provide us with the true facts, then it would be difficult to trust any of the social media intermediaries or any other source of information

There are different ways to conceptualize social issues from a sociological perspective. ${ }^{23}$ The sociological imagination empowers us to get a handle on biography and history and the relation between the two. ${ }^{24}$ That is its task. The major problem is the identification of such task ${ }^{25}$ i.e. categorization of social problem, when public at large characterize it as such: social issues are socially developed. ${ }^{26}$ An issue might be long-standing but we have seen that the problem gets attention and is considered as a social issue, when it begins to influence amazing and high class gatherings in a more noteworthy manner than previously and is given more consideration in the media. The sociological approach explains why issues of propaganda and sensationalized information have for quite some time been near, yet why fake news is presently in the public eye as a social issue. ${ }^{27}$

\section{Fake news: Contemporary Trends}

"Unmoderated content consumption is as dangerous as the consumption of sewage water." 28 Violence based on misinformation and disinformation is not a new phenomenon in India rather the spread of cell phones and web access in the nations poorest and the most disconnected zones has exacerbated the problem. In 2018 active social media users have increased to 326.1 million in India and also according to survey and the conclusion drawn from it, it is expected that the number of social media users to be almost 448 million in 2023.29

If we look at other countries their reports shows that the prime distributor of fake news is Facebook and twitter whereas WhatsApp is the prime distributor of fake news in two big democratic countries of the world i.e. India and Indonesia. According to the survey done by the BBC their reports shows that WhatsApp is the main driving force

21 Mooney, H. (2019). "Fake News" and the Sociological Imagination: Theory Informs Practice. Retrieved 8 September 2019, from http://hdl.handle.net/2027.42/143532

$22 \mathrm{Id}$.

23 D Bryant, C., \& L Peck, D. (2019). SAGE Reference - The Sociological Perspective. Retrieved 22 September 2019, from http:/ / sk.sagepub.com/reference/sociology/n1.xml

${ }_{24}$ C. Wright mills, Supra note 21.

25 C. Wright mills, Supra note 21.

26 Mooney, H, Supra note 22.

27 Mooney, H, Supra note 22.

28 Naskar, A. (2019). The Constitution of The United Peoples of Earth Quotes by Abhijit Naskar. Retrieved 10 September 2019, from https://www.goodreads.com/work/quotes/68019837-theconstitution-of-the-united-peoples-of-earth

29 Diwanji. S. (2019). India - number of social network users 2023 | Statista. Retrieved 6 September 2019, from https://www.statista.com/statistics/278407/number-of-social-network-users-in-india/ 
behind the spread of fake news in India. Fuelled by a distrust of mainstream news outlets, Indians are spreading data from alternative sources without verifying it. In doing so, they trust themselves to be promoting the "real story". ${ }^{30}$ In addition, Indonesia being the fourth most crowded nation on the planet with a similarly huge populace, fake news is common and negatively affects society. It had an influence in a few frequencies of common turmoil and caused disarray during times of emergency.

According to the survey done by the researchers which will be dealt in the upcoming chapter it showed that the maximum number of respondents uses WhatsApp as their medium of communication whereas in Indonesia according to the survey done by authorities there it showed that the $86 \%$ of respondents used WhatsApp for communication. ${ }^{31}$

After America, the countries especially the two democratic countries' elections suffered the most due to spread of fake news and the results got affected due to the same and those are India and Indonesia. The most common thing in India and Indonesia is that how fake news effects the elections and how it has created a hoax in the society and led to violence in different part of both the countries be it before election or post elections. Both the countries authorities had tried to respond to these mishappenings through campaigns, internet blackout and public alerts but it has given a very little success which equals to no success as compared to the level of problem with respect to the deterring the spread of fake news.

As WhatsApp has a huge user base in both the countries India as well as Indonesia, the government has been in talk with them to find out the ways to curb this menace through its platform. Now they are looking forward to work with Digital Strengthening Foundation, to make everyone aware about it and to work with network pioneers in around 10 states in the nation, including Karnataka, Jharkhand, West Bengal, Tripura, Maharashtra and Assam. On 29 August 2018 the founder director of DEF Mr. Osama Manzar said ${ }^{32}$ :

"We at WhatsApp and DEF hope these training workshops will help build an empathetic and conscious community of WhatsApp users who learn to respond rather than react to every message they receive"

Further in July 2018 came up with the system to clearly mark the "forwarded messages". It has also limited the occasion a message could be sent, to 5 times. The organization's delegates have expressed that they plan to help keep WhatsApp as it was proposed to be- a private informing application.

The barely recognizable difference that adjusts the crossing points of freedom and obligation is inborn in looking for legitimate (legal) cures, to keep pace with progressions in innovation. The threat of restriction and abridging the freedom of speech and expression is a genuine danger. Any certifiable exertion at battling the unfortunate implication of the mix of innovation i.e advance technology and human application should be established in a moral methodology that jelly the standard of human rights and free discourse.

30 What's driving India's fake news problem?. (2019). Retrieved 24 September 2019, from https://www.theweek.co.uk/97720/what-s-driving-india-s-fake-news-problem.

${ }^{31}$ MacKinnon, T. (2019). Case Study: Misinformation in Indonesia - GeoPoll. Retrieved 22 September 2019, from https://www.geopoll.com/misinformation-indonesia/

32 Gupta, K. (2019). WhatsApp ramps up user education drive to curb fake news. Retrieved 22 September 2019, from https://www.livemint.com/Companies/If4LwADEG6yWpNFYxEMnwN/WhatsApp-rampsup-user-education-drive-to-curb-fake-news.html 


\subsection{Fake News: Weapon for Mass Deception ${ }^{33}$ in India and Indonesia: Comparative Study}

\subsubsection{India}

Publicity and rumors have ruled the 2019 Lok Sabha election more than ever in the Indian political history. Even the union minister of communication, IT, and law Mr. Ravi Shanker Prasad on 24th July, 2019 informed that the Lok Sabha that recently had general and assembly elections reported 154 cases of fake news/misinformation and out of 15,446 cases came from Facebook, 97 from Twitter and 11 from YouTube. ${ }^{34}$ And the best example for this could be West Bengal, the hotbed of political savagery and a place to cast aspersions among pioneers of different ideological groups.

Claims of Muslim mollification against Mamata because of certain authoritative steps have just augmented the hole among Hindus and Muslims. Issues, for example, Imam remittances, moving Durga Puja immersion timings because of Muharram, and so forth have been adequately been utilized by genius Hindutva pages to fuel collective strains. This kind of energized the horrendous religious sentiments and world of politics is the ideal rearing ground for fake news and false accounts, and online life is frequently utilized as an enhancer for the equivalent. ${ }^{35}$

Now the question is, did these false or deceiving accounts really impact the democratic examples or modify the appointive outcomes in Bengal? Presumably a few issues viral via web-based networking media affected the discretionary result. Investigating the survey information of Lok Sabha voting public in West Bengal, India Today's Data Intelligence Unit has discovered that however the BJP improved its exhibition in this race, the gathering couldn't win even one of the nine seats that went to surveys in the seventh period of the Lok Sabha elections. 36

The election commission has given various guidelines regarding the election campaigns and tremendous use of social media, but due to the non existence of stringent laws regarding fake news it is affecting the public at large.

\subsubsection{Indonesia}

Indonesia 's revolts in May fill in as a notice to all popular governments with energized electorates, high web-based social networking infiltration and establishments working under the strain of populist legislative issues. The agitation was the first run through in a vote based system that web based life fuelled fake news and disinformation prompted political race riots. ${ }^{37}$

The misuse of innovative stages for political increases is in this manner a developing concern paving the way to the decisions. False information had misled and motivated many people associated with the Jakarta road violence. Aggressor oppositionists were activated by a course of fake news that finished in a conviction that their locale was

\footnotetext{
33 Fake videos and pictures were used as a weapon for mass deception.

34 Over 150 Cases of Fake News Reported during Lok Sabha Elections, Says Union Minister. (2019). Retrieved 11 September 2019, from https://www.news18.com/news/politics/over-150-cases-of-fakenews-reported-during-lok-sabha-elections-says-union-minister-2244463.html

${ }^{35} \mathrm{Id}$.

$36 \mathrm{Id}$.

37 Temby, Q. (2019). Indonesia's election riots offer a lesson on the perils of fake news. Retrieved 22 September 2019, from https://www.scmp.com/week-asia/politics/article/3026057/indonesias-electionriots-offer-lesson-perils-fake-news
} 
enduring an onslaught. With the predominant press to a great extent thoughtful to the legislature, those inciting the turmoil depended via web-based networking media stages - eminently scrambled talk applications, for example, WhatsApp and Telegram.

Some of the misinformation and disinformation is actually targeting the election process, trying to delegitimize it, which could be very dangerous," Nugroho told the Guardian. "If the election process is disputed then whoever is the winner, people may tend not to trust the results and it could be chaos. 38

A week before the presidential and administrative election on April 17, the spread of fake news has spiked. As indicated by information from the Indonesian Anti-Slander Society (MAFINDO), fake news (prevalently named "fabrications") have expanded by 61 percent between December a year ago and January 2019. The vast majority of the scams are found on long range informal communication stage Facebook. 39 The Indonesian Ministry for Communication and Information Technology detailed in excess of 700 political decision hoaxes in March 2019.40 Therefore some self regulatory measures should have been taken by to curb the problem of circulation of fake news over social media across the world.

Through the contextual analyses of India and Indonesia, unmistakably innovative and misshaped data sent during emotive occasions makes for a possibly flammable mix that may some way or another not be actuated. It is along these lines more pressing than any time in recent memory to all the more likely see how misinformation and disinformation movements happen via web-based networking media, especially during elections.

\subsection{Policy Intervention by Indonesia: Run War Room Fighting Indonesian Fake News $^{41}$}

In January 2018, President Joko Widodo selected a leader of the recently shaped National Cyber and Encryption Agency to help insight offices and law requirement endeavors battle online deception and scams before across the nation local surveys that late spring.

Reuters announced that the office was employing many individuals to "give security" to foundations on the web. While it's as yet indistinct what authority the body has, different offices have captured affirmed culprits of online deception. The legislature has additionally been blocking sites that distribute substance esteemed to be destructive for society.

The Jakarta Post revealed that web based life organizations are likewise working with the legislature to square and evacuate phony substance, just as illicit media, for example, sex entertainment. In late January, the administration additionally sent an instrument that purportedly consequently tracks and reports locales distributing counterfeit news stories.

\footnotetext{
38 Lamb, K. (2019). Fake news spikes in Indonesia, weeks ahead of elections. Retrieved 29 September 2019, from https://www.theguardian.com/world/2019/mar/20/fake-news-spikes-in-indonesia-aheadof-elections

39 Yang Hui,J. \& Pravin,P., (2019). Fake News in India and Indonesia's Elections 2019. Retrieved 22 September 2019, from https://thediplomat.com/2019/04/fake-news-in-india-and-indonesias-elections-2019/

$40 \mathrm{Id}$.

${ }^{41}$ Inside the government-run war room fighting Indonesian fake news. (2019). Retrieved 25 September 2019, from https://www.scmp.com/tech/policy/article/2170105/inside-government-run-war-roomfighting-indonesian-fake-news
} 
In October, Bloomberg announced that the Indonesian government has a group of 70 designers checking internet based life traffic 24 hours every day with an end goal to identify online falsehood.42 The purported "war room," which is housed inside the Ministry of Communications, is planned for checking the spread of falsities in front of a political race in April and has the power to expel posts that spread false news under a 2008 law.

The legislature has taken other considerable activities against falsehood. Per Bloomberg, the legislature has additionally made a site where individuals can report possibly false news and make sense of if it's actual or not. In September, the correspondences service declared that it would hold week after week briefings to expose deception. Furthermore, in April, authorities took steps to close down Facebook in the event that it neglected to get serious about deception in front of the political race. Indonesia's correspondences service reported in September that it would have week after week fake news briefings and busting deceptions through another site called StopHoax.id. 43

In November, Voice of America revealed that Indonesia's National Police had captured in excess of twelve individuals who spread false data via web-based networking media. The base sentence under the law is four years. In February 2019, with this as the foundation, UNESCO has built up the "Journalism, 'fake News', and Disinformation: A Handbook for Journalists" in 2018. This is implied as a guide to news coverage instructors to give greater quality data and know-hows to future columnists to fight fake news. So as to energize the utilization of the handbook in Indonesia, UNESCO is teaming up with Universities Gadjah Mada (UGM) in the interpretation and adjustment of the English handbook into Bahasa Indonesia just as to restrict the distribution to the Indonesian setting. The UNESCO handbook has been structured in accordance with the standards of UNESCO Media and Information Literacy program to make basically disapproved of clients and to adjust UNESCO's material to neighborhood setting. ${ }^{4}$

In May of 2019, the Indonesian government blocked access to certain online networking highlights for very nearly seven days following vicious uproars that broke out after the appointment of President Joko Widodo. The measure was required with an end goal to check the spread of tricks and calls for savagery that had spiked via web-based networking media systems. It anticipated clients on Twitter, Instagram, Facebook and WhatsApp from having the option to transfer photographs or recordings to the stages. In June 2019, an individual from the Muslim Cyber Army was captured in Java and accused of spreading counterfeit news and loathe discourse. The leader of the Indonesian National Police's Detective and General Crimes cybercrime division said the man had been in charge of spreading the unwarranted dread that the Indonesian government was being constrained by China.

42 A guide to anti-misinformation actions around the world - Poynter. (2019). Retrieved 22 September 2019, from https://www.poynter.org/ifcn/anti-misinformation-actions/\#indonesia

${ }^{43}$ Inside the government-run war room fighting Indonesian fake news. (2019). Retrieved 25 September 2019, from https://www.scmp.com/tech/policy/article/2170105/inside-government-run-war-room-fightingindonesian-fake-news

44 Indonesian Communication Schools Adapt UNESCO Manual to Fight Disinformation | United Nations Educational, Scientific and Cultural Organization. (2019). Retrieved 22 September 2019, from http://www.unesco.org/new/en/jakarta/about-this-office/singleview/news/indonesian_communication_schools_adapt_unesco_manual_to_figh/ 


\subsection{Analysis of Legislative Policy Intervention by India and Indonesia: ${ }^{45} \mathrm{~A}$ Comparative Study}

\subsubsection{India}

In India we have policy and laws to fight the evil of fake news but those laws are not stringent. Laws regarding the same are embedded in various statutes example people who disseminate fake news be it a content creator or content forwarder are prosecuted under the sections-124A, 153A, 153B, 295A, 500, and 505 of the Indian Penal Code, 1860 and we have The Information Technology Act, 2000 which is the first act to govern cyber law provisions in India sections like section 69, 79 earlier 66A was also considered for the same but the supreme court had held it to be unconstitutional in the case of Shreya Singhal case ${ }^{46}$.

The range of punishment under Indian Penal Code is between two years to five years, or fine, or both. Under the Section 67 of IT Act, spreading of fake news which is prurient is culpable with a term which may reach out to five years and with fine which may stretch out to one lakh rupees and in case of a second or subsequent conviction with detainment of either for a term which may reach out to ten years and furthermore with fine which may reach out to two lakh rupees.

Apart from this Indian government had come out with various strategies to control the situation like slowing down of internet and internet blackout but still these are not sufficient. So there is a need of some stringent law like anti fake laws in our countries to combat this evil.

\subsubsection{Indonesia}

Indonesia also has laws to combat this hoax only in its Criminal code. The issue is that the proposed law on fake news is wide to such an extent that everybody from hoax syndicate, to journalists, to the normal Indonesian who likes to share whatever they read via web-based networking media, can go through as long as six years in prison for spreading fake news. ${ }^{47}$

In a draft of the Revision of the Criminal Code dated January 10, 2018, the explanation about fake news appears in Article 30948:

Any person who broadcasts fake news or hoaxes resulting in a riot or disturbance shall be punished with a maximum imprisonment of six years or a maximum fine of Category III.

Any person who broadcasts or spread news through an information technology means resulting in a riot or disturbance, whereas the news are suspected to be fake or a hoax, shall be punished with a maximum imprisonment of four years or a maximum fine of Category II.

\footnotetext{
${ }^{45}$ Inside the government-run war room fighting Indonesian fake news. (2019). Retrieved 25 September 2019, from https://www.scmp.com/tech/policy/article/2170105/inside-government-run-war-roomfighting-indonesian-fake-news

46 Shreya Singhal v Union of India, (2013) 12 SCC 73.

47Tivany Wargadiredja, A. (2019). Indonesia's Answer to Fake News Is a Threat to Free Speech. Retrieved 26 September 2019, from https://www.vice.com/en_asia/article/j5bq54/indonesias-answer-tofake-news-might-be-a-threat-to-free-speech

$48 \mathrm{Id}$.
} 
However, there is a lot of problem because the article mentioned above give a vague idea for example the word "disturbance" there is no clarification regarding what they meant by this word and there are no parameters to decide whether the particular news or content is fake or not.

The legislature has taken other considerable activities against falsehood. As per Bloomberg, the legislature has additionally made a site where individuals can report possibly false news and make sense if it's actual or not. In September, the correspondences service declared that it would hold week after week briefings to expose deception. Furthermore, in April, authorities took steps to close down Facebook in the event that it neglected to get serious about deception in front of the political race. Indonesia's correspondences service reported in September that it would have week after week fake news briefings and busting deceptions through another site called StopHoax.id. ${ }^{49}$ Both the countries have laws but they are not stringent that is why the two biggest democracies of the country are facing the problem of this evil i.e. fake news.

\section{Conclusion}

Governments -incorporating into both these countries as both the countries are suffering through similar problem- must guarantee that any endeavors to counter "fake news" fall inside universal human-rights models, and are simply inspired by guaranteeing that voters can go to the polling booth well-educated. States likewise have the obligation to encourage a more extensive empowering condition for opportunity of articulation. This implies laws set up must not unduly limit an individual's opportunity to hold assessments or be utilized to stifle authentic reactions. States ought to likewise bolster the advancement of media decent variety, freedom, and access to data, as intends to stop disinformation, despise discourse and promulgation.

Due to advancement in digital media and increased use of the same has expelled the conventional watchman which existed in broadcasting media and print media, the free progression of messages has now turned into a reason for concern. The former has embedded itself in the fabric of Indonesian and Indian life and this reality is undeniable. In both the countries the discussion around the social media drove disinformation movement has been dominated by the hate speech on Whatsapp. And according to the survey done by the researcher it shows that the WhatsApp is the most used medium for communication and the most frequently used social networking site for circulation of fake news.

The political groups are utilizing the pace of advanced substance creation and preparing a casual base that would make and spread messages that suit their election campaigns, despite the fact that they may not be exactly precise. This is empowered by the asset they hold that are not transparent. Though both the countries are taking some steps to combat online extremism like signing of Christchurch to call action it is an international call initiated by the governments of New Zealand and France alongside top web-based social networking organizations after the Christchurch assaults. And had also forced the social media intermediaries like facebook, Google to remove fake

49 Walden, M. (2019). Ahead of 2019 Election, Indonesia, Media Battle Fake News. Retrieved 22 September 2019, from https://www.voanews.com/east-asia-pacific/ahead-2019-election-indonesia-media-battle-fakenews 
news site from their publicizing stages in light of the fact that they disregard strategies against deceiving content.

\section{Conflict of Interest Statement:}

The author(s) declares that the research was conducted in the absence of any commercial or financial relationships that could be construed as a potential conflict of interest.

Copyright $\odot 2019$ HALREV. All rights reserved. 